\title{
Characterization of Rice Husk and the Crystallization Process of Amorphous Silica from Rice Husk Ash
}

\author{
Ana Rivas, PhD ${ }^{l}$, Grace Vera, Eng. ${ }^{2}$, Julio Caceres, Eng. ${ }^{3}$,Víctor Palacios MSc. ${ }^{4}$, Andrés Rigail PhD ${ }^{5}$ Mauricio Cornejo PhD \\ ${ }^{1}$ Escuela Superior Politécnica del Litoral, ESPOL, FIMCP, Campus Gustavo Galindo Km 30.5 Vía Perimetral, P.O. Box 09-01- \\ 5863, Guayaquil, Ecuador. Universidad Simón Bolívar-Venezuela.arivasfe@espol.edu.ec or alrivas@usb.ve \\ ${ }^{6}$ ESPOL-Ecuador.mcornejo@espol.edu.ec \\ 22ESPOL.graanver@espol.edu.ec. ${ }^{3}$ ccaceres@espol.edu.ec,Espol. ${ }^{4}$ vpalacio@espol.edu.ec.ESPOL.5arigail@espol.edu.ec.
}

\begin{abstract}
Rice husk (RH) is a rich silica by-product of rice production with great potential for industrial applications. After combustion, a rice husk ash rich in silica is obtained, with some amount of other inorganic components constituted mainly of alkaline elements. The study was conducted to characterize both the rice husk and rice husk ash (RHA) in order to evaluate their constitution and the form in which mentioned impurities are present. The amorphous silica crystallized when heated under certain conditions. In this way, the examination of the crystallization process of rice husk ash with different impurity levels was also carried out by varying the temperature, time and heating conditions. The study reveals a preferential distribution of silica at the cell tip of the outer $\mathrm{RH}$ surface cells. The impurities form compounds with combinations of different elements such as $\mathrm{Ca}$ and $\mathrm{Mg}, P$ and $K$, and are mainly localized below the inner surface in the form of spherical and cuboidal shapes, as well as irregular morphologies.
\end{abstract}

Digital Object Identifier (DOI):

http://dx.doi.org/10.18687/LACCEI2016.1.1.093

ISBN: 978-0-9822896-9-3

ISSN: 2414-6390

$14^{\text {th }}$ LACCEI International Multi-Conference for Engineering, Education, and Technology: "Engineering Innovations for Global Sustainability", 20-22 July 2016, San José, Costa Rica. 


\title{
Characterization of Rice Husk and the Crystallization Process of Amorphous Silica from Rice Husk Ash
}

\author{
Ana Rivas, $\mathrm{PhD}^{1}$, Grace Vera, Eng. ${ }^{2}$, Julio Caceres, Eng. ${ }^{3}$,Víctor Palacios MSc. ${ }^{4}$, Andrés Rigail $\mathrm{PhD}^{5}$ Mauricio Cornejo $\mathrm{PhD}^{6}$ \\ ${ }^{1}$ Escuela Superior Politécnica del Litoral, ESPOL, FIMCP, Campus Gustavo Galindo Km 30.5 Vía Perimetral, P.O. Box 09-01- \\ 5863, Guayaquil,Ecuador. Universidad Simón Bolívar-Venezuela. arivasfe@espol.edu.ec or alrivas@usb.ve \\ ${ }^{6}$ ESPOL-Ecuador. mcornejo@espol.edu.ec \\ ${ }^{2}$ ESPOL.graanver@espol.edu.ec. ${ }^{3}$ ccaceres@espol.edu.ec, Espol. ${ }^{4}$ vpalacio@espol.edu.ec. ESPOL. ${ }^{5}$ arigail@espol.edu.ec.
}

\begin{abstract}
Rice husk (RH) is a rich silica by-product of rice production with great potential for industrial applications. After combustion, a rice husk ash rich in silica is obtained, with some amount of other inorganic components constituted mainly of alkaline elements. The study was conducted to characterize both the rice husk and rice husk ash (RHA) in order to evaluate their constitution and the form in which mentioned impurities are present. The amorphous silica crystallized when heated under certain conditions. In this way, the examination of the crystallization process of rice husk ash with different impurity levels was also carried out by varying the temperature, time and heating conditions. The study reveals a preferential distribution of silica at the cell tip of the outer $\mathrm{RH}$ surface cells. The impurities form compounds with combinations of different elements such as $C a$ and $M g, P$ and $K$, and are mainly localized below the inner surface in the form of spherical and cuboidal shapes, as well as irregular morphologies.
\end{abstract}

\section{INTRODUCTION}

Rice is harvested in large amounts worldwide, being the world paddy production in 2015 around 740 million tonnes. Rice hush (RH) represents about $20 \%$ of the rice grains, from which near 30 million tonnes of ash is feasible to obtain $(20 \%$ of rice husk). Rice husk, besides organic components constituted by cellulose, lignin and hemicellulose, also contains around $20 \%$ of silica $\left(\mathrm{SiO}_{2}\right)$. The combustion of organic components at temperatures between 550 and $700^{\circ} \mathrm{C}$ leads to rich silica ash $\left(\mathrm{SiO}_{2}\right)$ in an amorphous state. In this regard, unique characteristics of rice husk ash (RHA), such as high silica contents (87- 97 wt. \% SiO2), high porosity, low density, high surface area and low thermal conductivity makes it an alternative material for a variety of industrial applications [1]. During heating, the amorphous silica becomes crystalline, and the transition temperature for this transformation, as well as the type of phases formed, are highly affected by the level of impurities present in the RHA. The impurities commonly present in RHA are $\mathrm{K}, \mathrm{Ca}, \mathrm{P}$ and $\mathrm{Fe}$ in oxide form. These substances promote the formation of cristobalite and trydimite [2], affecting the structural transformation of silica from amorphous to crystalline state [3]. Additionally, the composition of $\mathrm{RH}$ is not unique, it varies depending on paddy type and source, soil fertilizers, climate conditions and sample preparation, among others [4].

Digital Object Identifier (DOI): http://dx.doi.org/10.18687/LACCEI2016.1.1.093 ISBN: 978-0-9822896-9-3

ISSN: $2414-6390$
Silica in the amorphous state is preferred for some potential applications of RHA, such as nitrides, carbides and other inorganic materials [5]. Thus, for those applications, it is of great interest to establish the most favorable conditions to keep the RHA silica in the amorphous state. In recent studies [6], the authors evaluated the evolution of silica crystallization by continuous heating in situ from room temperature to $1450^{\circ} \mathrm{C}$, highlighting the effect of impurity levels in this process. The transition temperature could also be affected by the heating mode. In this regard, the main purpose of this study is to evaluate the effect of isothermal heating on the amorphous- crystalline transformation of amorphous silica rich RHA. Moreover, the influence of different impurity concentration levels on amorphous- crystalline transformation will be assessed and the results are compared with those previously obtained by dynamic in situ heating. Furthermore, given the importance of the initial features of the rice hush on the amorphous to crystalline transformation, especially the impurities present in the material, a characterization of the samples was also performed by Fourier Transform Infrared (FTIR) Spectroscopy, Scanning Electron Microscopy (SEM) and X-Ray diffraction (XRD). The emphasis in the characterization was placed on the silicon distribution and type of impurities in the samples.

\section{EXPERIMENTAL PROCEDURE}

The procedure followed to prepare the samples is showed in Figure 1. Rice husk, collected from a rice mill in the region of Taura, Guayas-Ecuador, was washed in distillated water and dried. A portion of this sample was then pulverized to a granulometry lower than $40 \mu \mathrm{m}$, from which some samples were prepared for Fourier Transform Infrared (FTIR) analysis, with a Thermo Scientific Nicolet iS10-FTIR Spectrometer. Additionally, A single unit of rice hush in the as-received condition was analyzed by scanning electron microscopy (SEM), using a FEI- Inspect and Phenom 1255 microscopes.

A fraction of the washed and dried sample was directly calcinated at $650^{\circ} \mathrm{C}$ during $3 \mathrm{~h}$, and a second one was purified previous calcination, in a $1 \mathrm{NHCl}$ water solution during $16 \mathrm{~h}$. After the calcination process, these samples, labelled Sample 1

$14^{\text {th }}$ LACCEI International Multi-Conference for Engineering, Education, and Technology: "Engineering Innovations for Global Sustainability", 20-22 July 2016, San José, Costa Rica. 
and Sample 2, respectively, were analysed by a SEM Phenom 1255 microscope. Subsequently, both samples were subjected to static annealing to evaluate the crystallization process of the amorphous silica present in RHA. This heat treatment was performed in a furnace at temperatures between 800 and $1000^{\circ} \mathrm{C}$ during 2 and $6 \mathrm{~h}$, in order to evaluate the effect of temperature and soaking time on crystallization. After annealing some samples were analysed by X-ray diffraction (XRD), using a Panalytical X'Pert (40 kV, $30 \mathrm{~mA})$ X-ray diffractometer. Scans were taken with a $2 \theta$, step size of 0,017 and a counting time per step of $0,1 \mathrm{~s}$ using a $\mathrm{Cu}-\mathrm{K} \alpha$ radiation source $(\lambda=1.542 \AA)$. The isothermal crystallization results were then compared with those obtained by continuous heating carried out in situ, from room temperature up to $1450^{\circ} \mathrm{C}$ [6].

The constituents of the samples under study are displayed in Table 1. Apart from silica, the main components of the RHA are $\mathrm{K}_{2} \mathrm{O}, \mathrm{P}_{2} \mathrm{O}_{5}$ and $\mathrm{Ca} 0$ in amounts of 5.42, 2.95 and 2.77, respectively. Other impurities of $\mathrm{S}, \mathrm{Mn}, \mathrm{Fe}, \mathrm{Mg}, \mathrm{Al}, \mathrm{Cl}$ and $\mathrm{Zn}$ are also present in minor amounts. The sum of these impurities altogether is $1.44 \%$ for Sample 1 and $0.36 \%$ for Sample 2.

TABLE 1. Percentage of constituents on samples under investigation

\begin{tabular}{|c|c|c|}
\hline Component & \multicolumn{2}{|c|}{ Wt. (\%) } \\
\cline { 2 - 3 } Weight (\%) & Sample 1 & Sample 2 \\
\hline $\mathrm{SiO}_{2}$ & 87.39 & 96.94 \\
\hline $\mathrm{K}_{2} \mathrm{O}$ & 5.42 & 0.09 \\
\hline $\mathrm{P}_{2} \mathrm{O}_{5}$ & 2.95 & 1.94 \\
\hline $\mathrm{CaO}$ & 2.77 & 0.67 \\
\hline $\mathrm{SO}_{3}$ & 0.48 & - \\
\hline $\mathrm{MnO}_{\mathrm{Fe}_{2} \mathrm{O}_{3}}$ & 0.28 & 0.02 \\
\hline $\mathrm{MgO}_{\mathrm{Al}} \mathrm{O}_{3}$ & 0.24 & 0.14 \\
\hline $\mathrm{Cl}$ & 0.22 & - \\
\hline $\mathrm{ZnO}$ & 0.09 & 0.20 \\
\hline & 0.10 & - \\
\hline
\end{tabular}

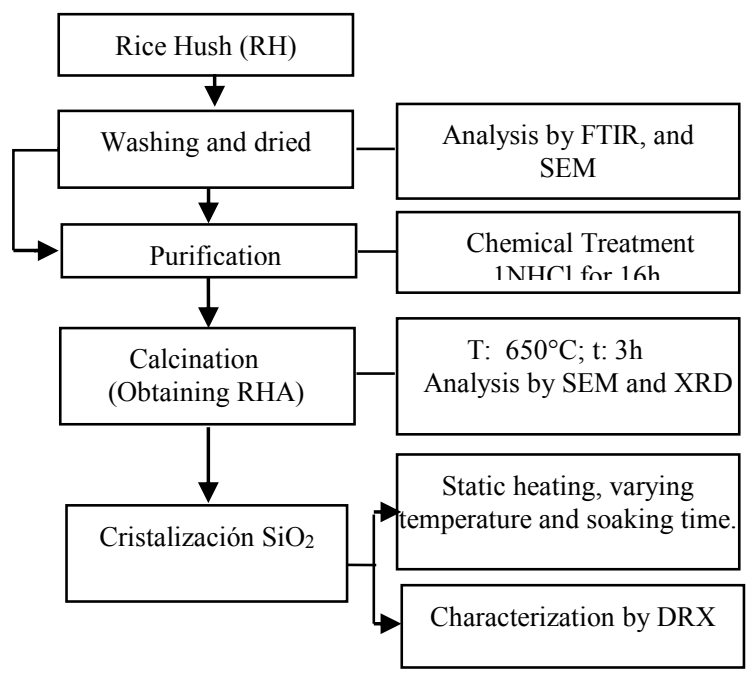

Figure 1. Scheme of experimental procedure followed in this study.

\section{RESULTS AND DISCUSSIONS}

\section{A. Fourier Transform Infrared Spectroscopy}

The FTIR patterns for samples of RH, are shown in Figure 2. These pattern display bands in the interval of wavenumbers between 500 and $4000 \mathrm{~cm}^{-1}$, the results coincide with those reported in the literature [7]. The band with wavenumber 3402 $\mathrm{cm}^{-1}$, located at the $\mathrm{OH}$ stretching zone, corresponds to the silanol (SiOH) group. The band centered at $2916 \mathrm{~cm}^{-1}$ corresponds to the methyl group attributed to the presence of lignin [7]. The stretching of aromatic rings are visualized by the wavenumber $1426 \mathrm{~cm}^{-1}$, while the groups $\mathrm{Si}-\mathrm{O}-\mathrm{Si}$ can be seen at $1100 \mathrm{~cm}^{-1}$ [8]. The bands centered at 800 and $464 \mathrm{~cm}^{-}$ ${ }^{1}$ are associated to the $\mathrm{Si}-\mathrm{H}$ bonds [9].

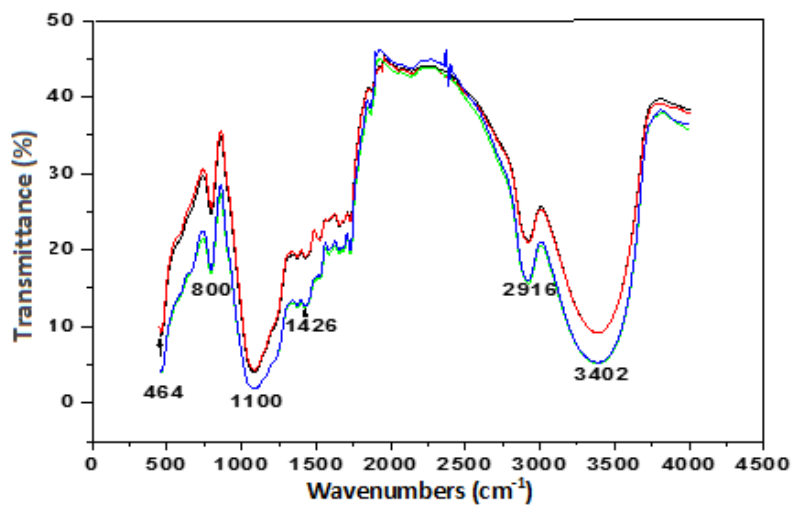

Figure 2. Curves of Fourier Transform Infrared for rice hush in the as-received condition.

\section{B. Scanning Electron Microscopy (SEM) of RH in the as- received condition and $R H A$ in the calcination condition}

Figure 3 shows a SEM image of a RH sample in the asreceived condition, showing both its external (a) and internal (b) surfaces. The outside surface, named exocarpo, is rough and has a characteristic wavy pattern, constituted by a symmetrically arrange of cones disposed in files along the whole surface. Each cone represents a cell [10]. Backscattered images (BSC) in figure 3C gives details of the $\mathrm{RH}$ outer zone. This figure shows the separation zones between cone files which are constituted mainly by organic material. Particular features of the inner zone are displayed in figure 3D. It is comprised by a vein-like structure, regularly spaced along the whole area with dispersed particle in between them. Figure 4 exhibits the EDS mapping analysis of silicon superimposed to SEM images taken at the outer (Fig. 5A) and inner (Fig. 5B) surfaces, together with oxygen mapping, figures $5 \mathrm{C}$ and $5 \mathrm{D}$, respectively. These elements in the external surface are mainly distributed on the cells tips. This is due to the fact that silicon is not present in $\mathrm{RH}$ in an elementary form, but rather as $\mathrm{SiO}_{2}$. On the other hand, at the inner surface both elements appear disperse everywhere, but with a weak signal.

$14^{\text {th }}$ LACCEI International Multi-Conference for Engineering, Education, and Technology: "Engineering Innovations for 


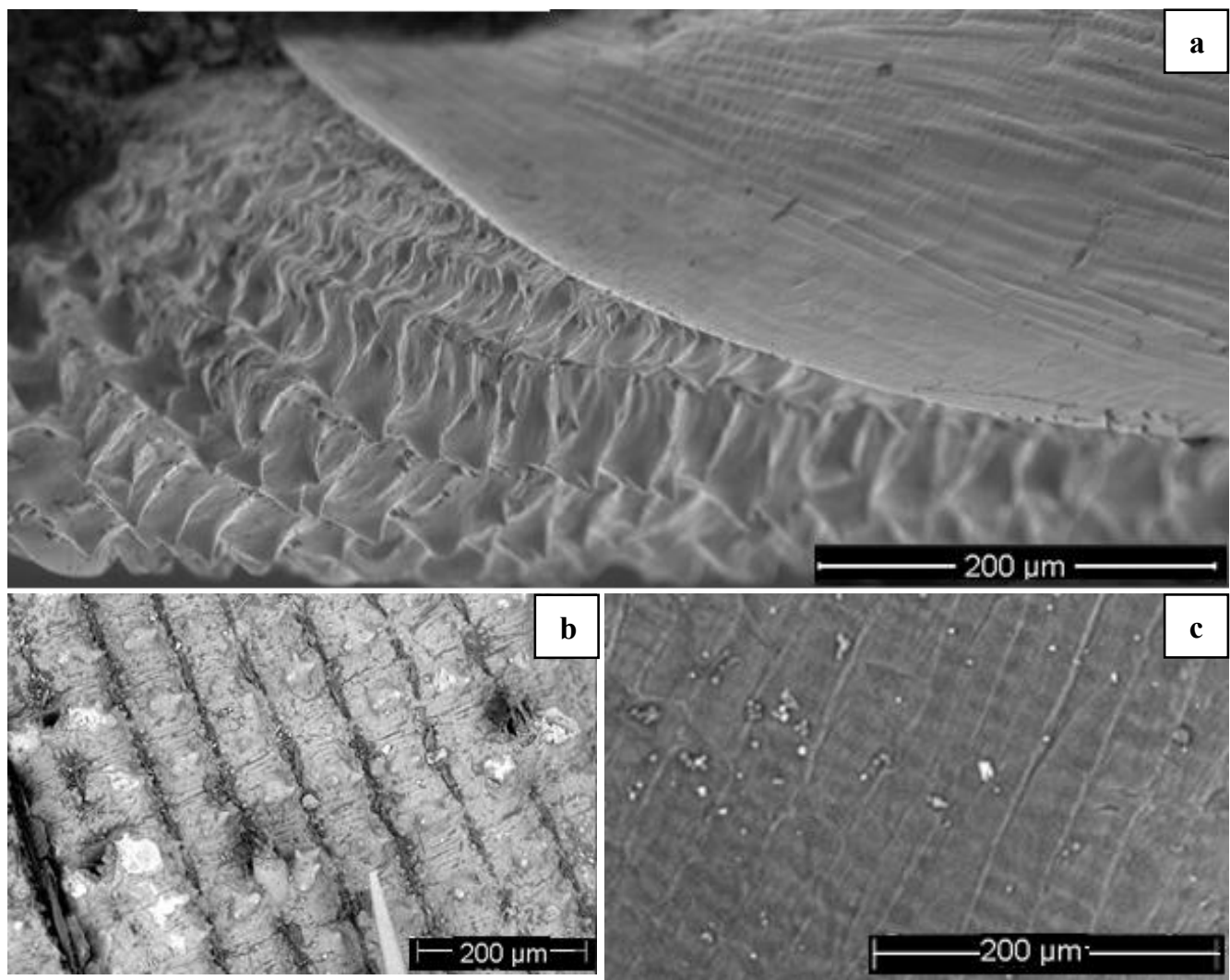

Figure 3. SEM image of RH in the as-received condition. a) general view. b and c) Details of external and inner surfaces, respectively.
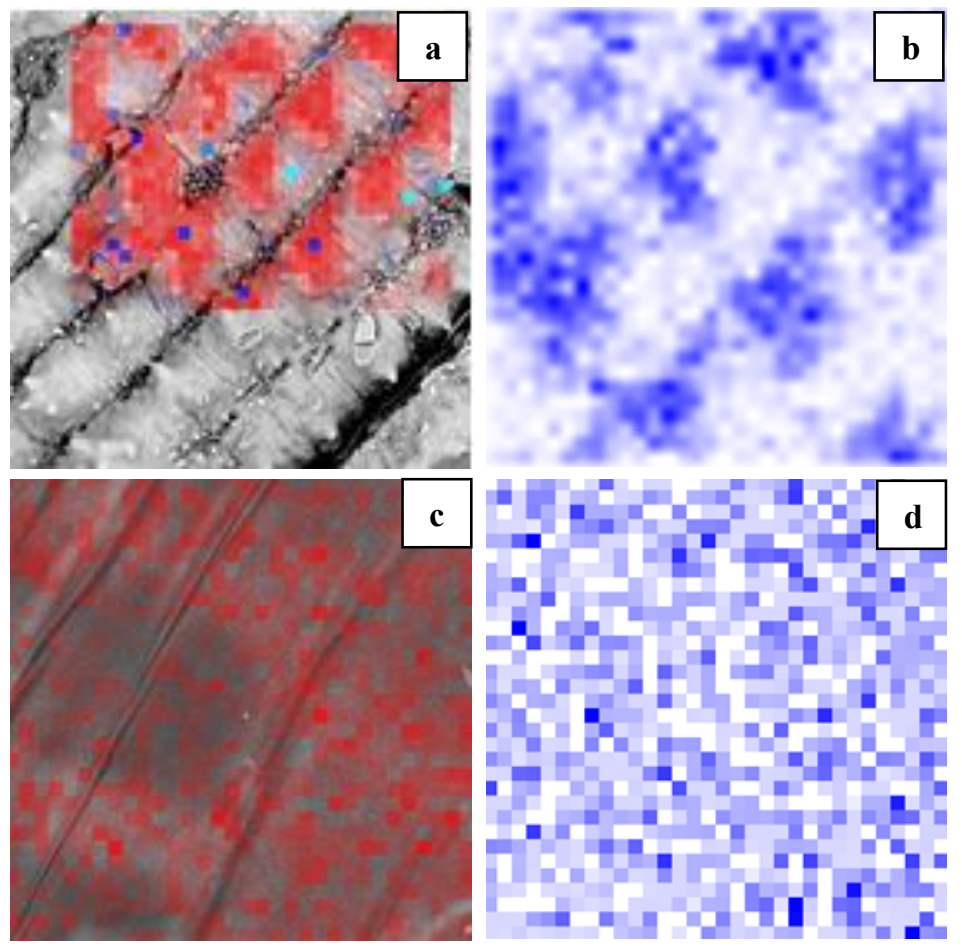

Figure 4. Silicon and oxygen maps on the outer and inner surfaces of RH, a) Outer surface SEM image with the mapping of Si superimposed to it. b) Oxygen map in the same area than Si in a). c) Inner surface SEM image with the mapping of Si superimposed to it. d) Oxygen map in the same area than Si in c) 
This suggests lower concentrations of silica in the interior of the RH. The distribution of silica in RH results is coincident with the reported by other researchers [11]. The silica together with lignin, provides resistance and rigidity to $\mathrm{RH}[12,13]$, protecting the $\mathrm{RH}$ from the surroundings.

Figure 5 shows a series of particles located at the outside and inside of RH. They have cuboidal, squares and spherical shapes, and are found on the top and below the inner surface. The particle marked with number 1 in Figure 5a, seems to be part of the inorganic components of the RH. Its EDS analysis displays in Figure 5d, shows a high carbon peak with no detection of any impurity elements. Figure 5 b, shows a zone where the skin layer of the inner surface was missing. This allows the observation of a significant number of particles inside the cavities at the interior of $\mathrm{RH}$. Some of them are seen in detailed in Fig 5c, corresponding to the area enclosed in circle in Figure 5b. The chemical composition of squares and spherical particles in this Figure 5c, are showed in Figures 5e and $\mathrm{f}$, respectively. Square particle 1 of Figure $5 \mathrm{c}$, is rich in $\mathrm{Ca}$, and particle 2 of spherical shape has $\mathrm{Mg}, \mathrm{P}$ and $\mathrm{K}$. The size of these spherical particles, also found over the inner surface, are lower than $3 \mu \mathrm{m}$, while the ones rich in $\mathrm{Ca}$ have sizes much greater. Given the distribution and location of impurities, the results suggest that for a more efficient purification of $\mathrm{RH}$, it is recommended to grind the $\mathrm{RH}$ in order to break the inner surface layer, and expose the impurities to the chemical solution.
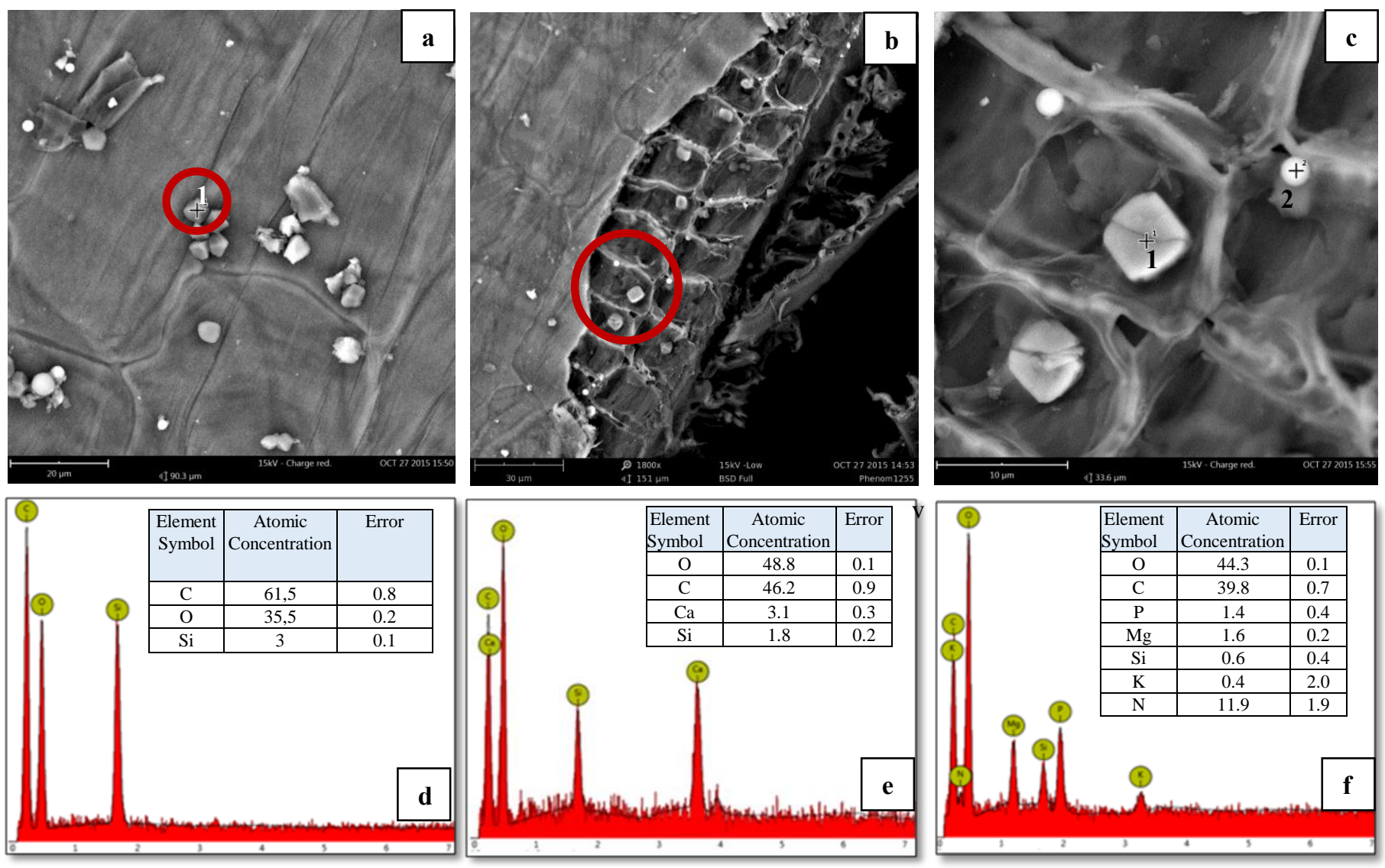

Figure 5. SEM images showing some components of RH with their respective EDS analysis, a) Inner surface.

b) Interior of sample showing below inner surface of RH. c) Detail of zone in Figure b enclosed in a circle.

d) EDS analysis of particle 1 enclosed in a circle in image a. e) and f) EDS analysis of particle 1 and 2 in image c, respectively.

14 ${ }^{\text {th }}$ LACCEI International Multi-Conference for Engineering, Education, and Technology: "Engineering Innovations for 
Figure 6 is an SEM image showing a general view of the RHA sample, obtained by calcination of $\mathrm{RH}$ at $650^{\circ} \mathrm{C}$ for $3 \mathrm{~h}$. In this figure, the outer, inner and transversal surfaces of RHA can be recognized. The RHA conserves the RH shape which is delineated by a rich silicon skeletal structure. The aforementioned structure seems to remain intact after burning the RH organic components, due to the rigidity of the material.

The densest zone of the RHA seems to be the outer part, distinguished by a regular waved zone that corresponds to the cells structure in the RH. This zone is detailed in Figure 6b, with non-open porous characteristics. This result is in contrast with the structure morphology of the depressed area that separate the files of cells in the RH, which is highly porous in nature after burning (Fig 6c). This part in the RH was mainly comprised by organic material, such as was showed by Figure 4e. The inner zone of the RHA is also porous. The evidence of these features are better observed at the cross section of the sample, which appears in Figure 6a. Such porous structure is accentuated by the removal of $\mathrm{RH}$ organic components by burning during calcination. The inner zone of the RH is mainly constituted by organic materials and therefore, have a lower concentration of silica (Fig. 4b). Thus, the only parts of the surface that seem to be dense are the cell tips, which are zones with less organic material (See Figure 4a).
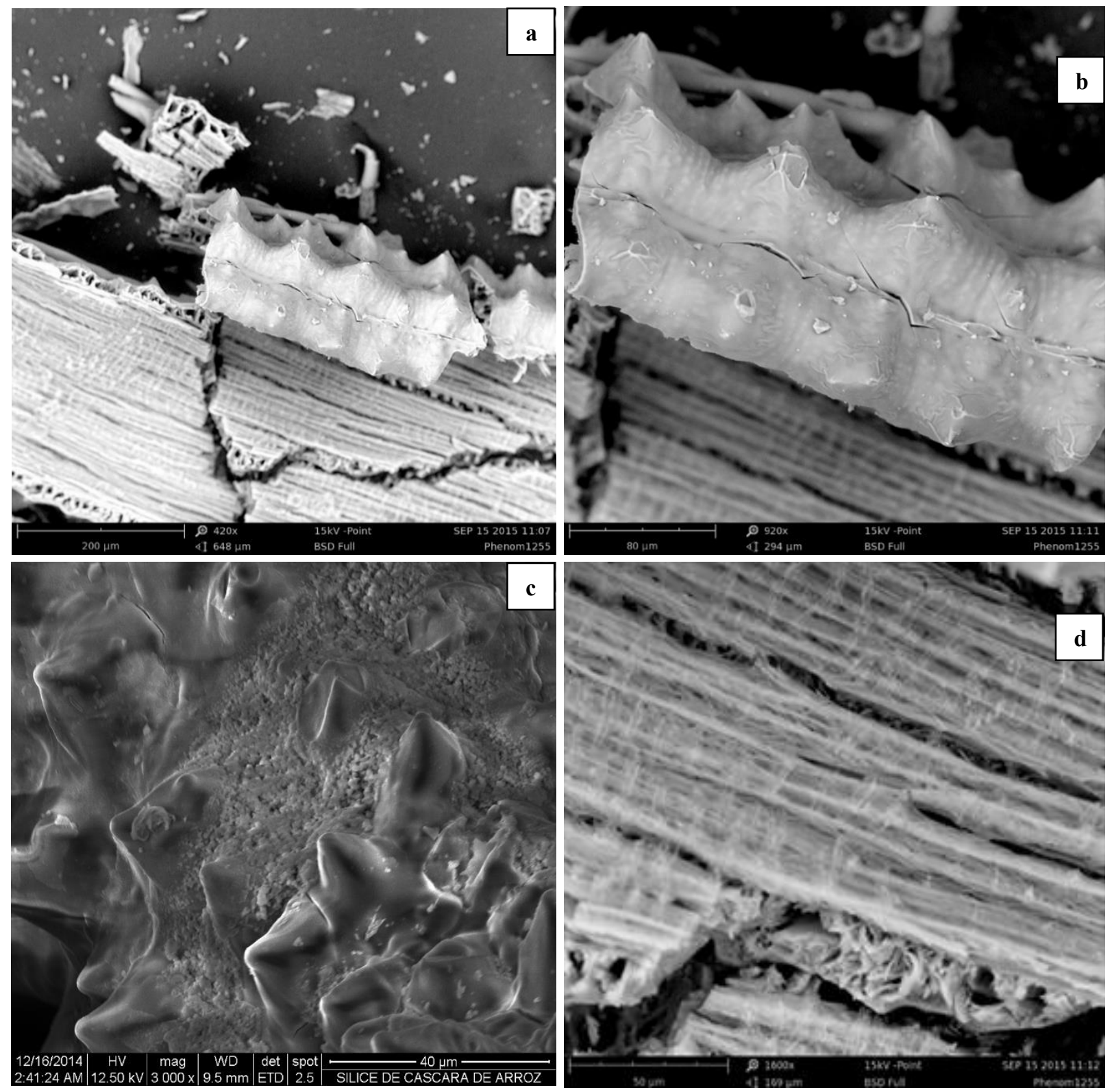

Figure 6. SEM images of Sample 1(calcinated without previous chemical treatment in $1 \mathrm{NHCl}$ solution).

a) General view. b) Outer surface; C) Detail of outer surface and c) Inner surface.

$14^{\text {th }}$ LACCEI International Multi-Conference for Engineering, Education, and Technology: "Engineering Innovations for 


\section{C. $X$ ray diffraction of RHA in the calcination condition and after isothermal heating}

Figure 7 contains the XRD pattern of RHA of samples 1 and 2. These patterns show a XRD profile typical of amorphous materials. Thus, at the calcination conditions $\left(650^{\circ} \mathrm{C}\right.$ and $\left.3 \mathrm{~h}\right)$, the RHA, abundant in silica, conserves the amorphous structure of $\mathrm{RH}$, which corroborates it amorphous nature. However, it is important to notice the difference of the diffraction peak amplitude between these two samples and also the small shift to the $2 \theta$ position of the diffused peak. In Sample 1, the peak measured at the half height of the peak is narrower than in Sample 2, and the diffuse peak is shifted to lower $2 \theta$ position. In $\mathrm{RH}$, the cellulose, found in $\mathrm{RH}$ is in amounts around 33\% [14], is the only component being reported to have a crystalline structure as a consequence of the interactions between Van der Waals forces between adjacent molecules [14]. The diffraction peaks of the cellulose are located at $2 \theta$ equal to $16^{\circ}, 22^{\circ}$ y $35^{\circ}$, being the highest intensity peak at $22^{\circ}$ [69]. Those peaks overlap with the background generated by amorphous components. In this case, it was possible to contrast the peaks by chemical treatment in a $4 \% \mathrm{NaOH}$ alkaline solution [15]. However, the cellulose decomposes in a temperature range between 250 and $350^{\circ} \mathrm{C}$. Therefore, the different features in XRD peaks cannot be attributed to the presence of cellulose. The basic difference between Sample 1 and 2 is the chemical composition which includes the carbon content and impurities. Therefore, it is possible that the cause for the difference in amplitude and $2 \theta$ position of the diffuse peak originates form differences in chemical composition in the samples.

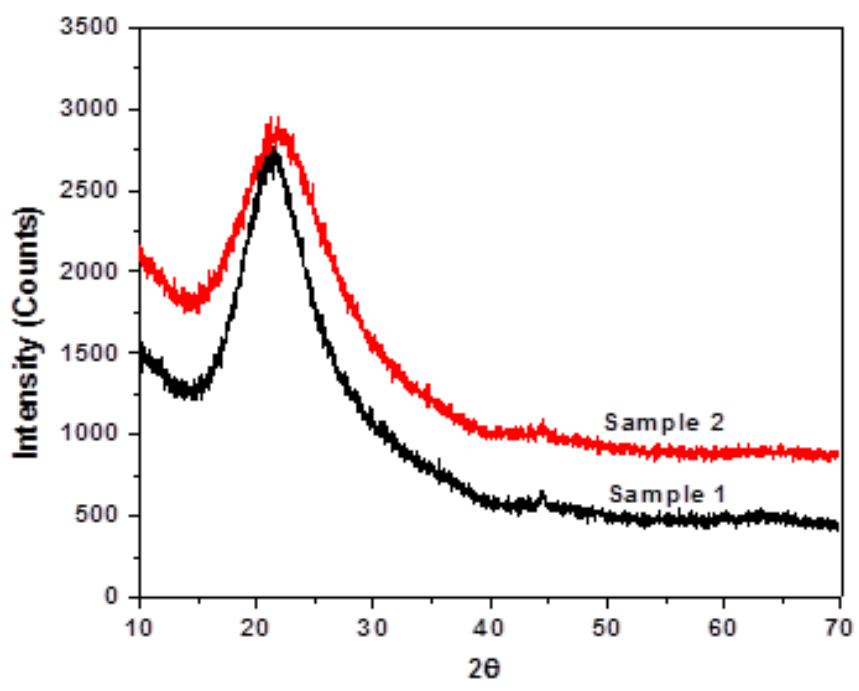

Figure 7 XRD patterns of Sample 1 and 2 in the calcinated condition
Figure 8 and 9 display the XRD patterns of samples isothermally heated from 800 to $1000^{\circ} \mathrm{C}$ for varying times. Sample 1 exhibits partial crystallization after exposure at $800^{\circ} \mathrm{C}$ for $6 \mathrm{~h}$ and undergoes complete transformation at $900^{\circ} \mathrm{C}$ within $2 \mathrm{~h}$. The crystallized state is composed of two phases, cristobalite and tridimite. On the other hand, in Figure 8 it can be seen that Sample 2 remains amorphous after $6 \mathrm{~h}$ of heating at $1000^{\circ} \mathrm{C}$. Sharp peaks around $44.7^{\circ}$ and $65^{\circ}$ are displayed in this figure. They are present in both samples and also in the original RHA (Figure 7), but the peak intensities become more pronounced after heating. However, the phase that leads to the appearance of these peaks decomposes with time at higher temperatures since the XRD peaks vanished after annealing the sample for $6 \mathrm{~h}$ at $1000^{\circ} \mathrm{C}$ (Figure 9). Although the phase that originates these peaks has not been identified, it is probably related to a complex phosphate since it is the major impurity in Sample 2. These findings, however, have not been reported in the literature and invites for further investigation.

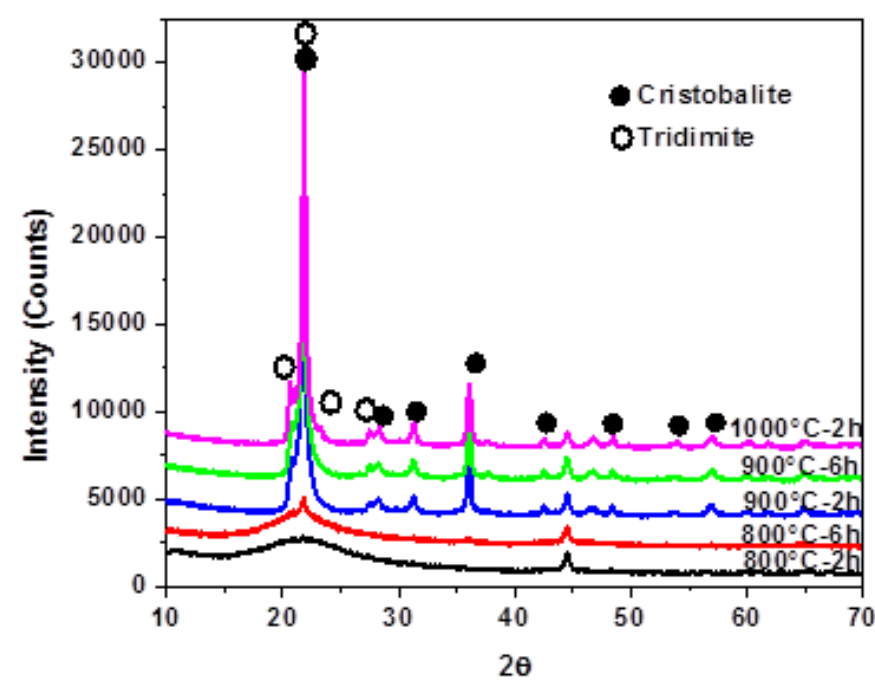

Figure 8. XRD patterns of Sample 1 isothermal annealing at $800^{\circ} \mathrm{C}, 900^{\circ} \mathrm{C}$ and $1000^{\circ} \mathrm{C}$ for 2 and $6 \mathrm{~h}$.

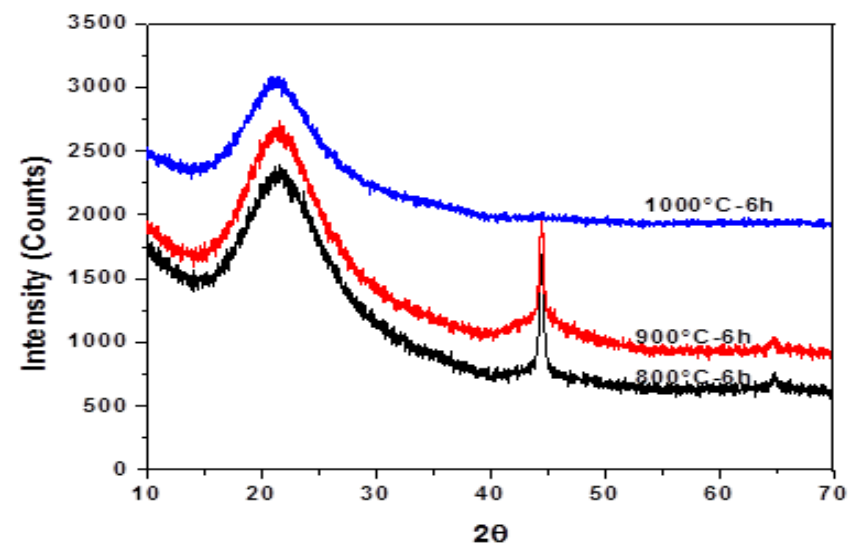

Figure 9. XRD pattern of Sample 2 after

$14^{\text {th }}$ LACCEI International Multi-Conference for Engineering, Education, and Technology: "Engineering Innovations for Global Sustainability", 20-22 July 2016, San José, Costa Rica. 
Table 1 shows the difference in chemical composition of the samples under investigation. The main impurity in Sample 1 is $\mathrm{K}$, found in a dioxide form; its concentration in Sample 1 is $5.42 \%$, while in Sample 2 is less than $0.10 \%$. As previously pointed out, the presence of alkaline elements promotes crystallization of amorphous silica at lower temperatures [16]. This behavior is due to their decomposition at low temperatures, which may produce low melting eutectic compounds with silica, thus favoring crystallization. Therefore, the results obtained upon isothermal heating are consistent with those expected. Sample 1 with higher amounts of impurities exhibited a transition from amorphous to crystalline phase at much lower temperatures than Sample 2. Moreover, at high temperatures the content of low melting impurities such as those based on potassium may decrease, which may raise the crystallization temperature.

Comparing these results of the crystallization temperatures of samples subjected to isothermal heating with those obtained by dynamic heating, it is found that the crystallization of amorphous silica, beside time and temperature, is also dependent on heating condition. It was found in previous work [6] that in Sample 1, the first trace of crystallization appears at $900^{\circ} \mathrm{C}$ and became entirely crystalline at $1200^{\circ} \mathrm{C}$, when heated continuously. On the other hand, in isothermal annealing, it starts to transform from amorphous to crystalline after $6 \mathrm{~h}$ at $800^{\circ} \mathrm{C}$ and the transformation is completed after $2 \mathrm{~h}$ at $900^{\circ} \mathrm{C}$. In contrast, Sample 2, begins to crystallize at temperatures greater than $1000^{\circ} \mathrm{C}$ in both continuous and isothermal heating. Therefore, in contrast with Sample 1, Sample 2 has an isothermal starting crystallization temperature above $1000^{\circ} \mathrm{C}$, similar to dynamic heating. This results could be associated with the increase in sample purity of Sample 2 at high temperatures, probably due to the decomposition of some impurity compounds present in the sample and subsequent evaporation. Such could be the case of the phase associated to the sharp peak located at $44.7^{\circ}$ and $65^{\circ}$ that disappears at $1000^{\circ} \mathrm{C}$ (Figure 9). It has been demonstrated that the higher the purity level of RHA, the higher the transition temperature from amorphous to crystalline is.

\section{CONCLUSIONS}

The silicon in RH is mainly concentrated at the tips of the cells located at the RH outer surface, with less content of organic material.

The impurities in the RH sample are located at the inner surface and in the interior, they exhibit different shapes and chemical compositions.
The crystallization process of RHA amorphous silica depends on its chemical composition, time, temperature and heating condition. The sample with greater levels of impurities and static heating, crystallize at lower temperatures. The crystallization temperature of amorphous RHA is raised with the increase in purity levels, while heating conditions do not show a remarkable influence.

\section{ACKNOWLEDGMENT}

The authors are thankful to the following institutions in Ecuador: Prometeo program of SENESCYT for sponsoring the present research; LEMAT- ESPOL for the support with the experimental work and X-Ray Diffraction; ANDEC S.A for the X-ray Fluorescence analysis and to Nanoinstrumentos for SEM + EDS analysis.

\section{REFERENCES}

[1] N. Soltani, A. Bahrami, M.I. Pech-Canul, L.A. Gonzalez. Review on the physicochemical treatments of rice husk for production of advanced materials. Chemical Engineering Journal 264 (2015) 899-935.

[2] Masashi HIGUCHI and Yasuo AZUMA. Journal of the Ceramic Society of Japan, 105 [5] (1997) 385-390 (in Japanese).

[3] Yasushi Shinohara and Norihiko Kohyama. Industrial Health, 42 (2004), 277-285,

[4] Iyenagbe B. Ugheoke and Othman MamatA critical assessment and new research directions of rice husk silica processing methods and propertiesMaejo Int. J. Sci. Technol. 2012, 6(03), 430-448.

[5] Chandrasekhar, K.G. Satyanarayana, P.N, Pramada and P. Raghavan. Journal of Materials Science 38 (2003) 3159-3168.

[6] Ana Rivas, Grace Vera, Víctor Palacios, Mauricio Cornejo, Andrés Rigail, Guillermo Solórzano. Phase transformation of amorphous rice husk silica. Unpublished.

[7] M. G. A. Vieira, A. F. de Almeida Neto, M. G. Carlos da Silva. C. Nóbrega and A. A. Melo Filho. Characterization and use of in natura and calcined rice husks for biosorption of heavy metals ions from aqueous effluents. Brazilian Journal of Chemical Engineering. Vol. 29, No. 03, (212) $619-633$.

[8] C. R. T. Tarley, y M. A. Z. Arruda, Biosorption of heavy metals using rice milling by-products. Characterization and application for removal of metals from aqueous effluents. Chemosphere, 54 (2004). 987-995.

[9] W. Nakbanpote, B.A. Goodman, Thiravetyan y Cooper adsorption on rice husk derived materials studied by EPR and FTIR. Colloids Surf, A. 304, 7-13 (2007).

[10] D. Napierska, L.C.J Thomassen, D. Lison, J. A Martens y P. H Hoet. La cascarilla de arroz como fuente de $\mathrm{SiO}_{2}$. Rev. Fac. Ing. Univ. Antioquia. N.o 41. pp. 7-20 (2007).

[11] B.-Dae Park, S. Gon Wi, Kwang H. Lee, A. P. Singh , T. H Yoon ${ }^{\mathrm{c}}$, Y. S. Kim Characterization of anatomical features and silica distribution in rice husk using microscopic and micro-analytical techniques, 1. Biomass and Bioenergy, Volume 25, Issue 3, September 2003, Pages 319-327.

[12] R.A. Ruseckaite, E. Ciannamea, P. Leiva, P.M. Stefan. Particle boards based on rice husk Polymer and Biopolymer Analysis and Characterization. Nova Science Publishing, Inc., New York. pp. 1-12.

[13] L. Ludeña, D. Fasce, V.A. Alvarez y P. M. Stefani. Nanocellulose from rice husk following alkaline treatment to remove silica. BioResources. 6(2). 1440-1453. (2011).

[14] J. Nurain, A. Ishak y D. Alain. Extraction, preparation and characterization of cellulose fibres and nanocrystals from rice husk. Industrial Crops and Products 37 (2012) 93-99.

$14^{\text {th }}$ LACCEI International Multi-Conference for Engineering, Education, and Technology: "Engineering Innovations for Global Sustainability", 20-22 July 2016, San José, Costa Rica. 
[15] Z., Y.P., Lynd, L.R., 2004. Toward an aggregated understanding of enzymatic hydrolysis of cellulose: noncomplex cellulose system. Biotechnology. Bioeng. 88(7) (2004), 797-824

[16] Omatola, K. M1 and Onojah, A. D.2. Elemental analysis of rice husk ash using X-ray fluorescence technique. International Journal of Physical Sciences, 4 (4), (2009) 189-193.

14 ${ }^{\text {th }}$ LACCEI International Multi-Conference for Engineering, Education, and Technology: "Engineering Innovations for Global Sustainability", 20-22 July 2016, San José, Costa Rica. 